\title{
An Analysis of the Insurance Industry Regulator in Saudi Arabia and Jordan through the Comparison with Insurance Industry Regulator in the UK
}

\author{
Doaa Mirah ${ }^{1}$ \& Ra'ed (Moh'd Taisir) Masa'deh ${ }^{2}$ \\ ${ }^{1}$ Business School, Manchester Metropolitan University, UK \\ ${ }^{2}$ Management Information Systems Department, Faculty of Business, The University of Jordan, Amman, Jordan \\ Tel: 962-6-535-5000 Ext. 24286. E-mail: r.masadeh@ju.edu.jo \\ Correspondence: Ra'ed (Moh'd Taisir) Masa'deh, Management Information Systems Department, Faculty of \\ Business, The University of Jordan, P.O. Box 13876 Amman 11942 Jordan. Tel: 962-6-535-5000 Ext. 24286. \\ E-mail: r.masadeh@ju.edu.jo
}

Received: December 12, 2013 Accepted: December 29, 2013 Online Published: January 27, 2014

doi:10.5539/ass.v10n3p211

URL: http://dx.doi.org/10.5539/ass.v10n3p211

\begin{abstract}
Since the Saudi Arabian Monetary Agency (SAMA) supervise and legalize the Saudi insurance sector, and as the Jordanian Insurance Commission (IC), which is an administratively and financially independent organization, regulates the local insurance sector; the purpose of this research is to critically examine the structure and functioning of insurance regulator in Saudi Arabia and Jordan through comparisons with the regulatory structure in UK. This is as an attempt to fill the lack of research in this vital area in order to arrive at constructive suggestions that could enhance the quality of insurance regulation in both countries. Indeed, this paper found that the insurance sector in Saudi Arabia and Jordan lags behind most of the other developing economies in Asia and Europe. Also, full implementation of the insurance regulatory Information System (IS) and publication of a clear regulatory ladder could support the taking of early and consistent intervention action on insurance companies.
\end{abstract}

Keywords: insurance industry regulator, KSA, Jordan, UK

\section{Introduction}

One of the most important and integral parts of the growth of insurance industry in any market is the regulatory control and development (Pearson, 2010). The role of a regulator in insurance industry is to ensure that the players in the industry adhere to the required standards of service and practice as well as to encourage the growth of the industry as a whole. Klein (1995) argued that the primary role of a regulator is not just to restrict but also to facilitate growth of the sector in an organized and controlled manner. The developments in regulatory aspect are typically in line with the broader market environments in the industry (OECD, 2001). Since it is seen that the regulators play a very important role in promoting a strong and scalable insurance industry it may be helpful to focus on structure of insurance regulator in the insurance sector of Saudi Arabia and Jordan. Saudi Arabia and Jordan have been chosen as case studies for this research on the basis of the fact that the countries are in unique positions to not only consolidate their leadership roles in Takaful but also to create a greater share for Takaful in the global insurance market. Also, they have already commenced the process of modernization of their financial institutions and regulatory frameworks. Hence, a comparison with the regulatory structure in a developed insurance market such as the UK could help to derive some important lessons for both countries.

It is seen that Saudi Arabian and Jordanian insurance industry and the role of regulator in the industry have been already studied by a number of researchers (Al-Rimawi, 1999; Al-Elg et al., 2006; Wahab et al., 2007; Ahmad et al., 2010; Kwon, 2013). Most of these researchers have focused on the concept of Takaful and have analyzed the growth of Takaful as well as the role of regulator in this context in Saudi Arabia (Takaful is a form of Islamic insurance in compliance with the principles of Shari'ah). This research attempts to find answers to the following review questions.

- What is present state and structure of insurance industry and the regulation of insurance industry in Saudi Arabia and Jordan? 


\section{- What are the issues with the present regulatory system in Saudi Arabia and Jordan?}

- What are the noteworthy points about UK's insurance regulation structure that could be of help in improving the quality of insurance regulation in Saudi Arabia and Jordan?

This research attempts to critically review some of the research papers and draw observations that could directly answer the questions stated above. This research is divided into a number of sections. The first section studies the state of insurance industry in Saudi Arabia and Jordan, and then examines the development and progress made until now. The second section focuses on the present structure of insurance regulation in Saudi Arabia and Jordan, and identifies some of the strengths of the present structure. The third section attempts to review some of the research papers that have critically examined the issues related to regulatory system that is present in Saudi Arabia and Jordan insurance industry. The final section is concerned with the research papers related to the progress of UK's insurance regulatory system. The purpose of the final section is to provide a basis for comparing the insurance regulatory system in Saudi Arabia and Jordan and in UK. This research purports to understand the level of research that has been conducted in this area of study so far and attempts to identify further points that may require further research.

\section{State of Insurance Industry in Saudi Arabia and Jordan}

The first section in this research attempts to gather a critical understanding of the state of insurance industry in Saudi Arabia and Jordan. Lester (2011) notes that the insurance sector in the entire Middle East and North African (MENA) region is underdeveloped in nature. The author argues that the insurance sector in Saudi Arabia has underperformed most of the other markets even within the MENA region. It is noted that the total life insurance premiums in Saudi Arabia stood at just $0.07 \%$ of the GDP (Gross Domestic Product) of the economy in 2009. In the overall MENA region, the average was at $0.28 \%$ in the same year. This evidently shows that the life insurance segment of the industry has significantly underperformed the peers from the same region. It is also observed by Lester (2011) that the GCC region as a whole has an average of about $0.23 \%$ of GDP in life insurance premiums. Quite notably the non-life premiums constitute a much higher $-0.46 \%$ of the total GDP of Saudi Arabia. Even though this much higher than life premiums, it still lags behind the GCC average of $0.87 \%$ and the MENA average of $0.97 \%$. Using these statistics the author clearly demonstrates that the insurance sector in Saudi Arabia lags behind not only the developed markets but also the other markets within the same Middle East region and GCC group. However, the statistics related to GDP may be slightly disadvantageous to Saudi Arabia due to the fact that the country has the highest level of GDP in the region primarily owing to the oil wealth. Another important observation, which Lester (2011) fails to make, is that the oil producing countries in MENA typically have a much lower percentage of GDP as premium than the non-oil countries. Specially, the life premium, as percentage of GDP, was $0.16 \%$ for the oil producing countries and $0.28 \%$ for non-oil producing countries. However, the general point to be noted from the observations made by Lester (2011) is that the insurance industry in Saudi Arabia is underdeveloped in comparison to the GDP and economic growth of the country as a whole.

Khan and Bhatti (2008) note that Takaful could have very strong potential for growth in Saudi Arabia given that the country is considered one of the most conservative followers of Islamic religion. However, the authors observe that in spite of the rapid oil-led economic growth and strong impetus, the growth of Takaful has been sluggish in Saudi Arabia due to regulatory frictions. The most notable issue related to Takaful in Saudi Arabia is stated to be that the regulations are developed on the basis of conventional insurance model and no special regulations exist for Takaful. The authors observe that countries such as Malaysia and UAE have seen significant progress by enacting separate regulations for Takaful companies. Ahmad et al. (2010) note that the shortage of human resources has been a major issue for insurance companies in Saudi Arabia. The failure of the regulatory agency to create strong growth impetus has created a situation where in the insurance companies are not willing to invest any significant capital in development of human resources required for the industry. Thus Ahmad et al. (2010) have noted an indirect impact of regulatory uncertainty on the industry as a whole. Visser (2009) noted that the insurance companies in Saudi Arabia have had significant issues in developing and getting approval of the regulator for the various insurance products or Takaful products. The bureaucratic processes involved in obtaining approvals have been stated to be a major hurdle in the progress of the insurance industry in Saudi Arabia.

Even though the researchers appear to concede that the insurance sector in Saudi Arabia has not reached a size that may be expected in an economy of Saudi Arabia's size, most of the researchers have noted that over the past few years the insurance industry in Saudi Arabia has seen rapid growth. Ansari (2011) notes that in 2004 the Saudi Arabian insurance industry went through a phase of reforms after which the growth in the industry has 
been impressive. The author cites some recent statistics to drive home the rapid growth witnessed by the industry in the last few years. Insurance penetration is defined as the Gross Written Premiums (GWP) divided by GDP of the economy. According to Ansari (2011), the insurance penetration level in Saudi Arabia increased steeply from just $0.62 \%$ in 2008 to $1.06 \%$ in 2009 . This represents a year on year increase of $69.9 \%$. Insurance density, which is defined as GWP per capita, of Saudi Arabia increased from SR440 in 2008 to SR576 in 2009, which represents a growth of $30.8 \%$. These statistics presented by Ansari (2011) clearly show that the insurance industry has indeed seen some rapid progress during the recent years even though it still lags behind most of the other markets in terms of size in comparison to GDP. However, Ramady (2011) presents an interesting observation about insurance industry in Saudi Arabia. The author notes that the growth in the insurance industry has been primarily coming from those areas that have benefited from mandatory insurance imposed by the government regulations. These are motor and health insurance products. Ramady (2011) observes that motor and health insurance together account for about $70 \%$ of the total insurance industry. Protection \& Savings products account for less than $7 \%$ of the total industry. Even though the insurance industry has been growing at about $30 \%$ per annum during the recent years most of this has come from the compulsory lines of business and not from the non-compulsory products. These statistics and observations made by Ramady (2011) present a very different perspective of the insurance industry in Saudi Arabia. This clearly shows that the customers in Saudi Arabia are driven towards insurance mostly because of government regulations and not necessarily due to any inherent demand for insurance products and services. Ramady (2011) also presents a comparison of the performance of insurance sector of Saudi Arabia to those of the other major countries of the world.

Also, the insurance sector in Saudi Arabia lags behind not only those in developed economies but also in developing economies. Further, the total premium received by Saudi Arabian insurance industry in 2009 was just USD 2.91 billion, which is very small when compared to USD 56 billion premiums generated by Indian insurance sector and USD 47 billion received by Brazilian insurance sector. Ramady (2011) showed that the insurance sector in Saudi Arabia constitutes a paltry $0.07 \%$ of the total insurance industry in the world. Even in this, most of the premiums are received on account of non-life products. The life insurance premiums in Saudi Arabia account for just $0.01 \%$ of the total life insurance premiums generated around the world. Another important observation to be made is that Saudi Arabia is one of the very few markets where the non-life premiums are multiple times more than the life premiums. In fact, in most of the developed and developing markets, the life insurance premiums are higher. This unique aspect of Saudi Arabia insurance sector may be attributed to the fact that motor and health, which are non-life products, are mandatory in Saudi Arabia while life insurance is not (Khorshid, 2004). Drechsler and Jütting (2007) note that the insurance sector in Saudi Arabia got a shot in the arm after the reforms that were introduced in 2004. The authors present a critical review of the important changes brought about in the sector by these reforms. The foremost change that caused a major positive difference to the sector was the allowance of private insurance players into the market, which was earlier dominated by only government insurance companies. This allowed a number of indigenous and international insurance players to enter the market. Even though the international players have not been allowed to operate without a local subsidiary this has not stopped them from setting up full-fledged operations in the country. Using data from various other countries, Drechsler and Jütting (2007) argue that private health insurance schemes have been better than the health insurance schemes offered by the government run insurance companies in most of the countries around the world. The authors present this as an argument to support the decision of the Saudi Arabian government to allow private insurance players into the market.

Although Jordan is notable among Arab countries in its insurance sector which has been free of state ownership in both the primary insurance and reinsurance markets, and has been spared the pervasive premium, product, investment and reinsurance controls that bedeviled the insurance markets of many developing countries around the world; the Jordanian insurance industry is not well developed. This primarily reflects the underdevelopment of life insurance, which has annual premiums of only 0.28 percent of GDP. Also, a level of well over 2 percent of GDP shows a satisfactory state of development. However, the level of general insurance (annual gross premiums of 1.65 percent of GDP) is similar to numerous other developing countries in the region and elsewhere (Vittas, 2004). Further, a key modernization attempt has been undertaken in recent years. This has entitled the endorsement of a new insurance law and the creation of a new insurance commission, which has made significant progress in expanding its staff, managing a wide-ranging training program to upgrade skills, and implementing a multi-year action plan to enhance the efficiency of the sector.

\section{Insurance Regulation in Saudi Arabia and Jordan}

A number of researchers have studied the structure and nature of insurance regulation in Saudi Arabia by comparing it to the other peers in the same Middle East region or GCC. Islam (2003) notes that the insurance 
regulation structures in GCC vary quite widely. The author observes that there are three different systems of insurance regulation commonly found in GCC states. The first type of regulation involves a common regulator for all kinds of financial services. These regulators are typically the central banks in most of the cases. Saudi Arabia is a case of such a structure wherein the central bank SAMA (Saudi Arabian Monetary Agency) is given the authority to oversee the insurance industry along with the other responsibilities of licensing and overseeing the financial services companies, banks and also making economic decisions in its capacity as the central bank. Bahrain also has a structure wherein the central bank of the country regulates all financial services businesses including insurance sector (IMF, 2006). The second structure of regulation in GCC, as identified by Islam (2003), involves the presence of an independent insurance regulator who has the complete authority over the insurance industry and the firms that are part of the industry. Specifically the authority has the rights to issue license to a company as well as to revoke the license. Such an independent authority typically has sufficient resources and powers to ensure smooth functioning of the insurance industry in general. UAE is one of the GCC states with an independent insurance authority. The third system of regulation in GCC is a composite model wherein there is an internal free zone or special purpose region where the regulation is performed by a different authority and outside the zone; the regulation is performed by the usual regulator. For example in the case of UAE, Dubai has a free zone called Dubai International Financial Centre (DIFC) which has its own regulator Dubai Financial Services Authority (DFSA) which is vested with powers to regulate all firms inside the free zone including the insurance firms (Mayes \& Wood, 2007). However, outside the free zone the insurance companies automatically fall under the regulation of the UAE insurance authority, which is an independent regulator for all insurance businesses inside the country. Thus, the GCC region has a complex network of insurance regulation. These observations made by Islam (2003) clearly show that insurance regulation remains a complicated affair within the GCC states. The multinational insurance companies may find it difficult to get accustomed to such varied structures of insurance regulation form one country to another even within the same region.

The research by Islam (2003) has shown the complexity in insurance regulation in GCC region as a whole. The focus of this research is on the insurance regulation in Saudi Arabia in particular. It is seen that Saudi Arabia has vested the powers related to insurance regulation with the central bank SAMA (Ramady, 2009). SAMA has the authority to license and regulate the operations of the firms in the insurance sector in general. There are two major laws related to insurance in Saudi Arabia. They are the cooperative health insurance law promulgated in 1999 and the law on supervision of cooperative insurance companies enacted in 2003. While the former is a specific law regulating the health insurance companies and the health insurance products of the general insurance companies, the latter is a law that is applicable commonly to all insurance companies as whole. The law on supervision of cooperative insurance companies was passed in 2003 and it is stated to have revolutionized the insurance sector as a whole. Earlier to this, there was no comprehensive law that governed the functioning and performance of the general insurance companies not engaged in health insurance business (Ramady, 2009). The cooperative insurance law clearly states that no company or entity can carry out any insurance business in Saudi Arabia without being licensed by a competent authority. The licensing authority in this case is the central bank of the country - SAMA.

The law states that the capital of the insurance company should not be less than SR 100,000,000 (USD 26.7 million). It is also stated that the paid up capital of a reinsurance company should not be less than SR 200,000,000 (USD 53.4 million). The new law also states very clearly that no insurance company can cease operations in the country without the prior approval of SAMA (Barakah \& Alsaleh, 2011). The law also has introduced some regulations on the financial affairs of the insurance companies. It is stated specifically that two different auditors should be appointed every year to audit the financial statements of the insurance company. These audited statements are required to be published and submitted to the authority before three months from the end of the financial year. Zakat is an Islamic tax derived on the basis of the principles of Shari'ah. Every year the insurance companies are required to contribute at least $20 \%$ of their profits to a reserve until the reserve reaches about $100 \%$ of the paid up capital of the company. The companies are also required to create and set aside a separate reserve for each one of the insurance classes that they undertake to deal in. These new regulations brought into force by the cooperative law passed in 2003 are stated to help strengthening of the insurance sector as a whole (Barakah \& Alsaleh, 2011). It is noted from the details discussed above that insurance regulation in Saudi Arabia has been a recent phenomenon with the main insurance law being less than a decade old. It is also interesting to note that the health insurance law predated the general insurance law, which means that the first insurance companies in the country were predominantly focused on health insurance.

Jaffer (2007) traces the development of health insurance in Saudi Arabia. The author notes that health insurance is one of the largest segments within the insurance sector of the country. Health insurance was also the foremost 
to evolve in the insurance sector in Saudi Arabia. Saudi Arabia has a separate law to regulate health insurance, which is termed Cooperative health insurance law, 1999. Health insurance in the country dates back to 1991 when the steering committee in Saudi Arabia recommended that health insurance should be made mandatory to all employers including the private companies. The new law passed in 1999 ensured that health insurance was made mandatory not only for the local population but also for expatriates and their families. One of the most important developments of this health insurance law was that it brought into presence a new independent authority for regulating health insurance in Saudi Arabia - Council of Cooperative Health Insurance (CCHI). $\mathrm{CCHI}$ has the overall authority over the regulation of health insurance companies and health insurance products of general insurance companies in the country. $\mathrm{CCHI}$ is also made a self-financing entity as it is vested with powers to collect $1 \%$ of the total gross premiums received by the health insurance firms. CCHI comes under the Ministry of Health but it includes representatives from various other ministries including interior, social affairs, finance, etc. Jaffer (2007) observes that the introduction of an independent authority for health insurance brought in more complexity into the regulatory system as the roles of SAMA and CCHI are not clearly defined in the law.

The review of insurance regulatory structure and the legislations in Saudi Arabia has presented a view that the structure is quite complex with multiple authorities involved. However, the insurance regulators in Saudi Arabia have had some success over the past few years in ensuring proper regulation of the sector and the active participation of major insurance players in the sector. By July 2011, there were 31 licensed insurance and reinsurance companies. However, in a market such as Saudi Arabia where the penetration of insurance is quite low, it requires more financial service providers to create awareness among the consumers about the benefits of insurance and to expand the market. As of the end of July 2011 there were 57 insurance brokers, 31 insurance agencies, 2 actuaries, 9 loss assessors and adjusters, 8 insurance claims settlement specialists, and 6 insurance advisors licensed and operating in the market (SAMA, 2013). This clearly shows that the regulations have not only created insurance companies but also have aided the growth of a complete ecosystem of service providers around these insurance companies so that together these players could contribute to the effective growth of the insurance sector in the country. This is stated to be one of the biggest achievements of the insurance regulators in the country. Another major strength of the present system is that the involvement of the central bank in the insurance regulation helps to align the insurance sector developments with the economic progress of the country. The central bank may be able to control the flow of capital into the country in the insurance sector through its policy changes thereby creating strong economic impetus as well.

The Jordanian insurance industry used to be regulated by an under-staffed and largely unproductive office that was part of the Ministry of Trade and Industry. The 1999 insurance act created the Insurance Commission (IC, 2013) as an independent and operationally autonomous regulatory agency (Vittas, 2004). Indeed, in order to protect consumers from deceptive packages and unfair practices, a helpful system of regulation and supervision is needed to set acceptable standards on market conduct and information disclosure. The IC rules involve the use of sound licensing and financial solvency criteria, whereas reducing the role of political favoritism and regulatory forbearance in deciding the fate of ailing companies. They depend on modern concepts of risk-based capital and solvency margin, reserving policies and reinsurance cover, and settlement procedures and market conduct. The new rules also emphasize the importance of proactive, risk-based supervision. However, some of the main difficulties of the Jordanian insurance industry contain the determination of sound reserving policies given the absence of a complete statistical databases on mortality, lapse and surrender rates and on loss experience, driving records, and other important aspects of insurance business; along with the implementation of fair value accounting rules in countries where asset markets are highly illiquid (Al-khabash \& Al-Thuneibat, 2009).

\section{Issues with the Present Regulatory System in Saudi Arabia and Jordan}

The previous section of this study has reviewed the general structure and development of insurance regulation in Saudi Arabian and Jordanian markets and it has also identified some of the important strengths of the system. The purpose of this section is to review some of the research papers that have identified some issues with the present regulatory system for insurance sector in both countries.

The foremost issue with the present insurance regulatory system in Saudi Arabia is that it includes two different regulators with authorities that could potentially overlap over each other's. SAMA is given the general authority to license and regulate the insurance companies while $\mathrm{CCHI}$ is made an independent authority exclusively for the health insurance segment. For the non-health insurance segments, there is high degree of clarity, as CCHI has no authority over these segments (Corneo, 2011). However, for the health insurance segment it is seen that there could be clash of powers between CCHI and SAMA. For health insurance companies there is a requirement for both licensing and accreditation. The licenses for insurance are issued by SAMA including those for the health 
insurance companies. The accreditation for the conduct of health insurance business is given by CCHI. Thus, the health insurance companies tend to get more regulated in the country than the other insurance companies. While the license to practice insurance is required to be renewed every year, the accreditation is provided for 3 years. Therefore, if a health insurance company fails to renew its license then it is possible that the company may be accredited but not licensed to practice insurance business in the country. For the non-health insurance companies SAMA has the authority to carry out annual audit. However, for the health insurance companies both SAMA and CCHI have the authority to initiate an audit. It is further complicated by the fact that CCHI has the authority to direct SAMA to conduct an audit of any health insurance company (SAMA, 2013). There are even more issues involved in the ways in which CCHI may choose to deal with erring health insurance companies. It is stated that $\mathrm{CCHI}$ has the authority to withdraw the licenses issued to these companies. Typically, in any regulatory set up, the authority, which provides the license, is the one that is vested with the authority to withdraw licenses as well. However in the case of health insurance in Saudi Arabia there could be a situation wherein the license issued by SAMA could be revoked by the authority of CCHI. Such a complicated situation could not only perplex the health insurance companies but also has the potential to cause clash of powers between the two regulators. These are some very important regulatory issues caused by multiple regulators in Saudi Arabia in health segment.

It can be noted from the above chart that top 8 companies account for about $67.6 \%$ of the total market in Saudi Arabian insurance sector. However, an interesting observation to be made from the chart is that only the top four players have been increasing their market share while all other players have been losing market share to these top players. This is caused by the fact that the top four players may have reached some level of economies of scale due to which they are able to expand their operations rapidly while the others who have not reached the required threshold for attaining economies have scale have been losing business. There is a very high degree of competition among the players in the market and this has caused the smaller players to suffer. Even though there are regulations that require the insurance brokers and agencies to be licensed in order to operate in the market there have been wide spread practice of individual agents marketing the products of international insurance companies on a one-to-one basis to the individuals. Since these international companies do not have to comply with the capital requirements, their costs from operations are quite low and so they offer insurance at highly competitive premiums when compared to the local players in the market. This has been a major problem for the regulators in the country.

Vayanous and Hammoud (2007) observe that one of the biggest issues with the regulatory system for insurance in Saudi Arabia is the wide spread prevalence of bureaucratic frictions. It is noted that the recent laws have radically expanded the powers of CCHI and SAMA in insurance regulation due to which there has been an increase in the delay in proceedings. The insurance companies are often made to wait for months before issuance or denial of licenses and other changes related to capital structure. This is one of the most important reasons why the international insurance players have generally stayed off the country's radar. There are also major issues involved in getting the schemes approved for Takaful insurance. The Takaful insurance schemes are required to be reviewed and approved by the Shari'ah board before the insurance regulators decide to approve these schemes. However, there are a number of problems faced by the takaful insurance providers in getting approvals due to the fact that some of the principles of Shari'ah are subject to interpretation and it may be possible for the Shari'ah board to interpret these principles in a manner that is unfavorable to these companies. The takaful companies are also required to comply with the same regulations as specified in the cooperative insurance law. It is stated that the takaful insurance model could be quite different from that of cooperative insurance model and so the takaful companies are compelled to adopt this new model in order to obtain approvals from the regulator. It is worth noting that UAE has a separate law for regulating takaful insurance companies and another law that is specifically applicable only to non-takaful companies. The lack of regulatory support is stated to be only of the reasons for low degree of penetration of takaful insurance in Saudi Arabia.

In addition, completing the modernization of Jordanian insurance regulation and supervision, and the restructuring and consolidation of the insurance industry are needed. Also, full implementation of the insurance regulatory Information System (IS) and publication of a clear regulatory ladder could assist the taking of early and consistent intervention action on weak companies. The Jordanian IC needs to build a concrete reputation for effectiveness and consistency in its intervention action. According to Vittas (2004), some concern is uttered by insurers regarding the cost of regulation, the risk of over-regulation, and the fast pace of implementation of the new instructions. Indeed, several researchers consider the IT and its flexibility as an enabler to achieve the desired competitive advantages, considered as a strategic weapon, and as a crucial support to operational and strategic business processes (Al Azmi et al., 2012; Alkalha et al., 2012; Altamony et al. 2012; Masa'deh, 2012; Masa'deh, 2013; Masa'deh, Shannak \& Maqableh, 2013). Further, some scholars (e.g. Shannak et al., 2010; 
Masa'deh \& Shannak, 2012; Shannak et al., 2012; Shannak, Obeidat \& Masa'deh, 2012; Shannak, Masa'deh \& Alkour, 2012; Kannan et al., 2013; Masa'deh et al. 2013) emphasize the need for large Jordanian firms to integrate their IT systems with their KM strategies and processes in order to survive in their highly competitive business environments.

\section{UK's Insurance Regulatory System}

One of the important objectives of this research is to review the insurance regulatory system in UK as means to identify some of the best and more evolved practices that Saudi Arabian and Jordanian insurance regulators may be able to adopt.

One of the most noteworthy aspects of insurance regulation is that there is a central regulator for all financial services ranging from capital market intermediation to insurance business. Financial Services Authority (FSA) acts as the central regulator for financial services in UK. This helps to prevent clutter in the regulatory framework and also enables the regulator to implement uniform policies across different industries within financial services sectors (Bruilt, 1999).

Another major aspect of regulation implemented by FSA is that it is adopts a risk-based approach. The purpose of regulator is to ensure that the firms are allowed to operate freely and in a manner that could promote their interests without affecting the quality of services or the interest of the customers or investors (Lastra, 2004). However, the regulator intends to control the firms on the basis of the risks that they add to the financial system as a whole. A firm that is engaged in a business that is less risky to the system such as investment advisory or research is regulated only to minimal extent while firms that are engaged in businesses that add substantial risks to the system such as mutual funds are regulated to a high extent. This kind of regulation ensures that the regulator focuses on the firms that are likely to engage in high risk activities while spending less time regulating the firms that do not pose much risk to the financial system (Vives, 2001).

The regulatory system adopted by FSA also differentiates between different sizes of firms (Luna-Martinez \& Rose, 2003). A large firm is regulated significantly more than a small firm is. A large firm typically deals with a large number of clients and engages in transactions that are of large sizes. Therefore, these firms may pose greater risks to the system. On the other hand, smaller firms have only a few clients or have only small transactions, which even at the worst level may not add much incremental risks to the financial system. Therefore, the regulations are focused more on controlling large firms. By doing so, the smaller firms are allowed to grow freely to a certain extent with minimal compliance costs. This presents ample scope for the small firms to grow in the market. However, as these firms continue to grow the regulatory pressure also increases substantially (Luna-Martinez \& Rose, 2003). Thus, the regulatory pressure is maximized for large firms, which are likely to have the resources and means to meet these high compliance costs without affecting their businesses. These are some of the most important aspects of the insurance regulatory system in UK that may be of significance for the Saudi and Jordanian insurance regulators.

\section{Research Methodology}

As stated earlier, the proposed research will adopt a comparative approach to arriving at the critical findings related to functioning of insurance regulator and its structure in Saudi Arabia and Jordan. It is observed that the information related to this topic may be available from a number of secondary sources such as the annual report published by SAMA (Central Bank) and Jordanian insurance commission, research papers, and articles in press. However, a more appropriate source of information could be the managers of the insurance companies in Saudi Arabia and Jordan as the managers may be involved in the various aspects related to regulation of their business in the market and so may be in a better position to provide a highly informed view of the regulatory scene in the industry. Therefore, it is suggested that the proposed research should adopt a primary research methodology as the means to obtaining information and analyzing it. A qualitative approach may be required in this case as the information related to insurance regulation may not necessarily be in quantitative form. This research involves primary research wherein information related to benefits and limitations of the existing regulatory structure as well as the suggestions for future development in regulation will be obtained from managers of the insurance companies in Saudi Arabia and Jordan. The data collection will be completed using interviews as interviews may provide valuable opportunities for the researchers to interact with the management personnel in the target organizations and to acquire useful information and knowledge related to the research subject. Secondary information may be used to perform the comparison of regulators of insurance sector in Saudi Arabia and Jordan with UK. The comparative analysis will focus on major aspects including degree of control, facilitation function, depth of knowledge, presence of appropriate legislations, structure of regulatory authority, and influence on legislative developments. 


\section{Conclusion}

On the basis of review performed in this research, it is seen that the insurance sector in Saudi Arabia and Jordan, though rapidly growing, lags behind most of the other developing economies in Asia and Europe. From the review of literature it is noted that only a handful of researchers have studied the state of regulatory system in Saudi Arabia and Jordan. The lack of robust research in this area presents an opportunity for this research to focus on the regulatory system in Saudi Arabia and Jordan. The research question that is derived from this objective is "What is the present state of regulatory system in Saudi Arabia and Jordan?". The regulatory structure for insurance includes an overall regulator - SAMA and an independent regulatory authority only for health insurance segment - CCHI. It is noted that this dichotomous structure creates significant overlap of authority in health insurance segment. This leads to a research question "What are the major advantages and limitations of the insurance regulatory system in Saudi Arabia and Jordan?" From the review of regulatory system of UK, it is observed that the single regulator system may have significant advantages. Further, the risk-based approach to regulation ensures that the regulator focuses on those firms and segments that are likely to add substantial risks to the financial system. Through this review, it is observed that only a few researchers have focused on comparative study of insurance regulatory system in Saudi Arabia and Jordan. Even those handfuls of researchers who have studied this topic have often compared the insurance regulatory environment in different countries in GCC or Middle East. No significant attempt has been made to compare the regulatory system of Saudi Arabia or Jordan to a more evolved system such as that of UK's so that better lessons could be learnt. This is an important gap in research in this area, which needs to be filled. This leads to a research question - "What are the important areas in which developments could be made in Saudi Arabia's and Jordan's insurance regulatory systems, in comparison to that of UK?".

\section{References}

Ahmad, M. I., Masood, T. K., \& Khan, M. S. (2010). Problems and prospects of Islamic banking: A case study of Takaful. MPRA Paper, University Library of Munich, Germany.

Al Azmi, N., Al-Lozi, M., Al-Zu'bi, Z., Dahiyat, S., \& Masa'deh, R. (2012). Patients attitudes toward service quality and its impact on their satisfaction in physical therapy in KSA hospitals. European Journal of Social Sciences, 34(2), 300-314.

Al-Elg, A., \& Hoque, M. (2006). Charting changes in Saudi Arabian insurance industry. Working Paper, King Fahd University of Petroleum \& Minerals.

Alkalha, Z., Al-Zu'bi, Z., Al-Dmour, H., Alshurideh, M., \& Masa'deh, R. (2012, August). Investigating the effects of human resource policies on organizational performance: An empirical study on commercial banks operating in Jordan. European Journal of Economics, Finance and Administrative Sciences, 51, 44-64.

Al-khabash, A., \& Al-Thuneibat, A. (2009). Earnings management practices from the perspective of external and internal auditors: Evidence from Jordan. Managerial Auditing Journal, 24(1), 58-80. http://dx.doi.org/10.1108/02686900910919901

Al-Rimawi, L. (1999). Emerging markets of the Middle East: A critique of selected issues in Arab securities regulation. Journal of Financial Regulation and Compliance, 7(2), 149-176. http://dx.doi.org/10.1108/eb025005

Altamony, H., Masa'deh, R, Alshurideh, M., \& Obeidat, B. (2012). Information systems for competitive advantage: Implementation of an organisational strategic management process. The 18th IBIMA Conference on Innovation and Sustainable Economic Competitive Advantage: From Regional Development to World Economic, Istanbul, Turkey, 9th-10th May.

Ansari, Z. A. (2011). Analysis of the impact of reforms on insurance industry of Saudi Arabia. Interdisciplinary Journal of Research in Business, 1(8), 28-37.

Barakah, D. M., \& Alsaleh, S. A. (2011). The cooperative insurance in Saudi Arabia: A nucleus to health reform policy. Proceedings of the International Conference on Information and Finance, Singapore.

Bruilt, C. (1999). The rationale for a single national financial services regulator. Financial Services Authority Occasional Paper No. 2.

Corneo, G. (2011). Stakeholding as a new development strategy for Saudi Arabia. Review of Middle East Economics and Finance, 7(1).

Drechsler, D., \& Jütting, J. (2007). Different countries, different needs: The role of private health insurance in developing countries. Journal of Health Politics, Policy and Law, 32(3), 497-534. 
http://dx.doi.org/10.1215/03616878-2007-012

IMF. (2006). Kingdom of Bahrain: Financial System Stability Assessment, Including Reports on the Observance of Standards and Codes on the Following Topics, Banking Supervision, Insurance Supervision, Securities Regulation, and Anti-Money Laundering and Combating the Financing of Terrorism. Washington: IMF.

Insurance Commission (IC). (2013). The Kingdom of Jordanian insurance sector. Retrieved from http://www.irc.gov.jo/home.asp

Islam, M. M. (2003). Regulations and supervision of financial institutions in GCC countries. Managerial Finance, 29(7), 17-42. http://dx.doi.org/10.1108/03074350310768328

Jaffer, S. (2007). Islamic insurance: Trends, opportunities and the future of takaful. London: Euromoney Books.

Kanaan, R., Masa'deh, R., \& Gharaibeh, A. (2013). The impact of knowledge sharing enablers on knowledge sharing capability: An empirical study on Jordanian telecommunication firms. European Scientific Journal, 9(22), 237-258.

Khan, N. M., \& Bhatti, M. I. (2008). Islamic banking and finance: On its way to globalization. Managerial Finance, 34(10), 708-725. http://dx.doi.org/10.1108/03074350810891029

Khorshid, A. (2004). Islamic insurance: A modern approach to Islamic banking. London: Routledge. http://dx.doi.org/10.4324/9780203458280

Klein, R. W. (1995). Insurance regulation in transition. The Journal of Risk and Insurance, 62(3), 363-404. http://dx.doi.org/10.2307/253816

Kwon, W. (2013). The significance of regulatory orientation, political stability and culture on consumption and price adequacy in insurance markets. The Journal of Risk Management, 14(4), 320-343.

Lastra, R. M. (2004). Governance structure for financial regulation and supervision in Europe. Columbia Journal of European Law, 10, 49-60.

Lester, R. R. (2011). The insurance sector in the Middle East and North Africa: Challenges and development agenda. World Bank Policy Research Working Paper No. 5608.

Luna-Martinez, J., \& Rose, T. G. (2003). International survey of integrated financial sector supervision. World Bank Policy Research Working Paper No. 3096.

Masa'deh, R. (2012). The impact of Management Information Systems (MIS) on Quality Assurance (QA): A case study in Jordan. International Journal of Information, Business and Management, 4(2), 93-110.

Masa'deh, R. (2013). The impact of information technology infrastructure flexibility on firm performance: An empirical study of Jordanian public shareholding firms. Jordan Journal of Business Administration, 9(1), 204-224.

Masa'deh, R., \& Shannak, R. (2012). Intermediary effects of knowledge management strategy and learning orientation on strategic alignment and firm performance. Research Journal of International Studies, 24, $112-128$.

Masa'deh, R., Gharaibeh, A., Maqableh, M., \& Karajeh, H. (2013). An empirical study of antecedents and outcomes of knowledge sharing capability in Jordanian telecommunication firms: A structural equation modeling approach. Life Science Journal, 10(4), 2284-2296.

Masa'deh, R., Shannak, R., \& Maqableh, M. (2013). A structural equation modeling approach for determining antecedents and outcomes of students' attitude toward mobile commerce adoption. Life Science Journal, 10(4), 2321-2333.

Mayes, D. G., \& Wood, G. E. (2007). The structure of financial regulation. London: Taylor \& Francis. http://dx.doi.org/10.4324/9780203962312

OECD. (2011). Insurance regulation and supervision in Asia and Latin America. Paris: OECD Publishing.

Pearson, R. (2010). The development of international insurance. London: Pickering \& Chatto.

Ramady, M. A. (2009). Evolving banking regulation and supervision: A case study of the Saudi Arabian Monetary Agency (SAMA). International Journal of Islamic and Middle Eastern Finance and Management, 2(3), 235-250. http://dx.doi.org/10.1108/17538390910986353

Ramady, M. A. (2011). The Saudi Arabian economy: Policies, achievements, and challenges. UK: Springer.

Saudi Arabian Monetary Agency (SAMA). (2013). The Knigdom of Saudi Arabia insurance sector. Retrieved 
from http://www.sama.gov.sa/sites/samaen/insurance/pages/home.aspx

Shannak, R., Masa'deh, R., \& Akour, M. (2012). Knowledge management strategy building: Literature review. European Scientific Journal, 8(15), 143-168.

Shannak, R., Masa'deh, R., Al-Zu'bi, Z., Obeidat, B., Alshurideh, M., \& Altamony, H. (2012). A theoretical perspective on the relationship between knowledge management systems, customer knowledge management, and firm competitive advantage. European Journal of Social Sciences, 32(4), 520-532.

Shannak, R., Masa'deh, R., Obeidat, B., \& Almajali, D. (2010). Information technology investments: A literature review. The 14th IBIMA Conference on Global Business Transformation through Innovation and Knowledge Management: An Academic Perspective, Istanbul-Turkey, 23rd-24th June, pp.1356-1368.

Shannak, R., Obeidat, B., \& Masa'deh, R. (2012). Culture and the implementation process of strategic decisions in Jordan. Journal of Management Research, 4(4), 257-281. http://dx.doi.org/10.5296/jmr.v4i4.2160

Vayanous, P., \& Hammoud, M. (2007). Promoting the growth and competitiveness of the insurance sector in the Arab world. Booz Allen Hamilton.

Visser, H. (2009). Islamic finance: Principles and practice. Gloucester: Edward Elgar Publishing.

Vittas, D. (2004). Insurance regulation in Jordan new rules - old system. World Bank Policy Research Working Paper No. 3298.

Vives, X. (2001). Restructuring financial regulation in the European monetary union. Journal of Financial Services Research, 19(1), 57-82. http://dx.doi.org/10.1023/A:1011133401170

Wahab, A. R., Lewis, M. K., \& Hassan, M. K. (2007). Islamic takaful: Business models, Shariah concerns, and proposed solutions. Thunderbird International Business Review, 49(3), 371-396. http://dx.doi.org/10.1002/tie.20148

\section{Copyrights}

Copyright for this article is retained by the author(s), with first publication rights granted to the journal.

This is an open-access article distributed under the terms and conditions of the Creative Commons Attribution license (http://creativecommons.org/licenses/by/3.0/). 